\title{
Repeated Tramadol Administration Induced Bleeding in Albino Rats
}

\author{
Hanem Mohammed Roshdy ${ }^{1}$, Rania Hamed Abdel-Rahman ${ }^{1}$, Hanan Azzam ${ }^{2}$ and \\ Amal Abd El-Salam El-Bakary ${ }^{1}$
}

\begin{tabular}{ll}
\hline & ABSTRACT \\
\cline { 2 - 3 } $\begin{array}{l}\text { KEYWORDS } \\
\text { Tramadol, }\end{array}$ & $\begin{array}{c}\text { Tramadol abuse is a major health problem. Its effects on hemostasis showed } \\
\text { Bleeding, }\end{array}$ \\
PT, & $\begin{array}{l}\text { controversial findings. The aim of the present study was to investigate the subchronic toxic } \\
\text { effects of tramadol on some hemostatic parameters in Wistar albino rats. Before } \\
\text { performance of the study, bleeding time, prothrombin time (PT), activated partial }\end{array}$ \\
APTT, & $\begin{array}{l}\text { thromboplastin time (APTT) as well as Adenosine Diphosphate (ADP) induced platelet } \\
\text { aggregation percentage were measured to get reference values for normal levels. Rats were } \\
\text { Albino rats }\end{array}$ \\
$\begin{array}{l}\text { then given tramadol by gavage in a dose of } 20 \text { mg/kg once daily for six weeks and the } \\
\text { previously mentioned haematological parameters were measured at two, four and six } \\
\text { weeks. The results reveal that tramadol enhanced bleeding tendency along the six weeks of } \\
\text { the study as evidenced by prolonged bleeding time, PT, APTT, and decreased ADP- } \\
\text { induced platelet aggregation. It can be concluded that tramadol could affect hemostatic } \\
\text { parameters in favour of bleeding tendency. Further studies are warranted to confirm these } \\
\text { effects and to investigate the possible underlying mechanisms and the potential reversibility } \\
\text { of toxicity after drug abstinence. }\end{array}$
\end{tabular}

\section{Introduction}

Data highlight the increased incidence of tramadol abuse especially in North Africa and Middle East (WHO, 2014). Noteworthy, tramadol is illicitly trafficked with the aim to decrease pain, increase endurance power, and to alter sensations (Santacrocea et al., 2018). Tramadol abuse became a major health problem in Egypt due to its low price, illegal transaction and availability with no prescription from pharmacies, black market and media as reported by Ismaiel and Hosny (2012).

Tramadol effects on hemostasis showed controversial results. It has been claimed that

\footnotetext{
${ }^{(1)}$ Forensic Medicine and Clinical Toxicology Department, Faculty of Medicine, Mansoura University.

(2) Clinical Pathology Department, Mansoura University.
}

tramadol reduced the procoagulant actions of serotonin and norepinephrine resulting in reduction of thrombus weight (McMillan et al., 2008; Galan et al., 2009; Hallbäck et al., 2012). Moreover, hemorrhage has been reported in tramadol treated patients following tonsillectomy (Courtney and Cabraal, 2001; Işik et al., 2009).

It has been described that tramadol can be safely used in patients undergoing surgery in terms of hemodynamic and respiratory side effects. However, there have been no sufficient studies on the direct effects of tramadol on hemostasis (Bilir et al., 2014). Hence, the aim of the present work was to investigate the subchronic toxic effects of repeated administration of tramadol on some hemostatic parameters in adult albino rats. 


\section{Material and Methods}

Study design and animals:

The present work is a repeated dose subchronic toxicity study of tramadol which was performed in the Medical Experimental Research Center (MERC), Faculty of Medicine, Mansoura University. Fifteen Wistar albino rats weighing 180-200 g, were obtained from MERC. They were housed in clean cages under standardized laboratory conditions including good lighting (12 hours light/dark cycles) and good aeration. They were fed a standard laboratory diet and tap water. All procedures were approved by the Institutional Review Board of Faculty of Medicine (code number: MS/16.05.21).

\section{Tramadol administration and samples collection:}

Before performance of the study, bleeding time was measured, then two milliliter blood samples were collected from retro-orbital plexus in all rats to measure prothrombin time (PT), activated partial thromboplastin time (APTT) and Adenosine Diphosphate-induced platelet aggregation (ADP) percentage. Results were used as reference values for normal levels (zero time). Thereafter, rats were given Tramal (Tramadol $\mathrm{HCl}$ capsules $(50 \mathrm{mg}$ ), Mina-Pharm, Egypt) in a dose of $20 \mathrm{mg} / \mathrm{kg}$ once daily (according to a preliminary pilot study) for six weeks. The calculated doses were delivered in normal saline and given orally to each animal by gavage. This dose equals $7 \%$ of the LD50 (oral LD50 values are around $300-350 \mathrm{mg} / \mathrm{kg}$ body weight for rats) as stated by Matthiesen et al. (1998). Then, bleeding time, PT, APTT and ADP induced platelet aggregation percentage were measured at two, four and six weeks after tramadol administration. Blood samples were homogenized and stored at room temperature in sterile tubes containing 3.2\% sodium citrate. The citrated samples were spun at (150-200 rpm) for 10 minutes to obtain the platelet rich plasma that was used for platelet aggregation tests and then samples were further spun at (2000 rpm) for 10 minutes to obtain the platelet-poor plasma to estimate prothrombin time and activated partial thromboplastin time.

\section{Haematological investigations:}

1) Bleeding time was performed by puncture with a specific scalpel in the vein located on the external surface of the ear. Time from puncture to the end of bleeding was measured in seconds by a chronometer (Brondani et al., 2009).

2) Prothrombin time was estimated using Thromborel S Reagent (Siemens Healthcare Diagnostics products, Marburg, Germany) as described by Quick et al. (1935).

3) Activated partial thromboplastin time was measured in seconds using Pathromtin SL (Siemens Healthcare Diagnostics products, Marburg, Germany) according to Brondani et al. (2009).

4) ADP-induced platelet aggregation percentage was estimated using optical chrono-log platelet lumi-aggregometer (Chrono-Log Corp., Havertown, Pennsylvania, USA). The assay is based on the measurement of the increase in light transmission through the optically dense sample of platelet rich plasma after the addition of ADP as an exogenous platelet agonist (Brondani et al., 2009; Paniccia et al., 2015). 


\section{Statistical analysis}

Results were analyzed by using the computerized statistical package for the social sciences (SPSS) version 20.0. Data was tabulated as mean \pm standard deviation (SD) for quantitative analysis. Student t-test was used to detect the significant change of the parameters in comparison to control samples. Statistical significance was realized at probability $\mathrm{p} \leq 0.05$.

\section{Results}

The effects of repeated tramadol administration on different haemostatic parameters in the studied groups of albino rats were demonstrated in table (1). There was progressive significant increase in bleeding time on repeated doses (after two, four and six weeks) compared to the reference value at zero time (base level). It also produced insignificant increase in prothrombin time (PT). Activated partial thromboplastin time (APTT) is insignificantly increased at two and six weeks, while it significantly decreased at four weeks. There was also a significant increase in ADPinduced platelet aggregation after tramadol administration at two and six weeks duration.

Table (1): Effects of repeated tramadol administration on different haemostatic parameters in the studied groups of albino rats ( $\mathrm{n}=60$ samples).

\begin{tabular}{|c|c|c|c|c|}
\hline \multirow[b]{2}{*}{ Haemostatic parameters } & \multicolumn{4}{|c|}{ Study groups } \\
\hline & $\begin{array}{l}\text { Reference } \\
\text { group (zero } \\
\text { time) }(n=15)\end{array}$ & $\begin{array}{c}2 \text { weeks } \\
(n=15)\end{array}$ & $\begin{array}{l}4 \text { weeks } \\
(n=15)\end{array}$ & $\begin{array}{c}6 \text { weeks } \\
(n=15)\end{array}$ \\
\hline Bleeding time & $28.13 \pm 5.15$ & $34.73 \pm 8.88 \uparrow$ & $42.66 \pm 4.169 \uparrow$ & $53.6 \pm 6.114 \uparrow$ \\
\hline $\mathbf{p}$ & & $<0.001 *$ & $<0.001 *$ & $<0.001 *$ \\
\hline P1 & & & $<0.001 *$ & $0.001 *$ \\
\hline p2 & & & & $<0.001 *$ \\
\hline Prothrombin time & $16.30 \pm 0.965$ & $16.89 \pm 924 \uparrow$ & $16.40 \pm 825 \uparrow$ & $17.02 \pm 2.621 \uparrow$ \\
\hline p & & 0.161 & 0.717 & 0.298 \\
\hline p1 & & & 0.161 & 0.86 \\
\hline p2 & & & & 0.4 \\
\hline APTT & $25.64 \pm 3.13$ & $26.62 \pm 6.123 \uparrow$ & $23.58 \pm 2.126 \downarrow$ & $24.63 \pm 2.102 \downarrow$ \\
\hline $\mathbf{p}$ & & 0.47 & $0.019^{*}$ & 0.22 \\
\hline p1 & & & $0.05 *$ & 0.17 \\
\hline p2 & & & & 0.08 \\
\hline $\begin{array}{l}\text { ADP induced platelet } \\
\text { aggregation percentage }\end{array}$ & $63.69 \pm 19.5$ & $79.10 \pm 15.58 \uparrow$ & $59.85 \pm 14.92 \downarrow$ & $78.67 \pm 17.42 \uparrow$ \\
\hline $\mathbf{p}$ & & $0.05^{*}$ & 0.5 & 0.07 \\
\hline p1 & & & $0.003 *$ & 0.39 \\
\hline p2 & & & & $0.001 *$ \\
\hline
\end{tabular}

$\mathrm{n}$ : number, all values are expressed as (mean $\pm \mathrm{SD}$ ), SD: standard deviation, APTT: activated partial thromboplastin time,ADP: adenosine diphosphate. $\mathrm{p}$ : Comparison with reference levels, $\mathrm{p}_{1}$ : comparison of four and six weeks with two weeks duration $\mathrm{p}_{2}$ : comparison of six weeks with four weeks duration *: significant at $\mathrm{p}<0.05$. 


\section{Discussion}

Debate regarding the effect of tramadol on bleeding profile exists in the literature (Brondani et al., 2009; Işik et al., 2009). In the present work, oral tramadol administration $(20 \mathrm{mg} / \mathrm{kg})$ to albino rats produces progressive significant increase in bleeding time on repeated doses (after two, four and six weeks) compared to the reference value at zero time (base level) as shown in table (1).

Bleeding time depends largely on the rate of formation of platelet plug and is affected by both platelet count and function (Adhikary and Jacob, 2005). Studies on the direct effect of tramadol on bleeding time are insufficient and most of the researchers focussed on studying the effect of tramadol on other hematological parameters including platelet count. For instance, tramadol signifycantly decreased platelet count in domestic rabbits (Aldalou et al., 2014) and rats (Nna et al., 2016).

The exact mechanism of decreased platelet count is not clear, however, it may be attributed to the presence of drug-dependent antibodies or drug metabolites that bind to glycoproteins (GPs) on the platelets (Arnold et al., 2013). It may be also explained by the disturbed manufacture of thrombopoeitin as a result of tramadol-induced liver dysfunction leading to decreased platelet production (Lisman et al., 2002). It is known that long term repeated use of tramadol exposes the liver to toxic injury with increased alanine transaminase levels indicating the failing functions of liver cells (Saleem et al., 2014; Hafez et al., 2015). Hence, prolonged bleeding time may be due to decreased platelet count that was unfortunately not measured in the present study.

The present findings reveal that tramadol produced insignificant increase in prothrombin time (PT) after two, four and six weeks compared to the base reference values. Activated partial thromboplastin time (APTT) is also insignificantly increased at two and six weeks, while it significantly decreased at four weeks compared to the reference base levels.

Prolonged PT was previously reported by Taromsari et al. (2012) in patients intoxicated with tramadol. Furthermore, Bilir and his colleagues (2014) studied the in vitro effects of tramadol on coagulation system and found that blood medicated with high-dose tramadol (6 $\mu \mathrm{l} / \mathrm{ml}$ ) clotted slowly.

Similarly, Hafez et al. (2015) investigated the toxic impact of tramadol in albino rats. They used four different intramuscular doses of tramadol; $12.5 \mathrm{mg}, 25 \mathrm{mg}, 50 \mathrm{mg}$ and 300 $\mathrm{mg} / \mathrm{kg} /$ day for two weeks. There were significant increases in prothrombin time and activated partial thromboplastin time. The results were explained by liver dysfunction after long term use of tramadol.

It is known that PT and APTT reflect the integrity of the extrinsic and common coagulation pathways (Slaughter, 2010). Furthermore, abnormal APTT is a mirror for most of the coagulation factor deficiencies except factor VII (Adhikary and Jacob, 2005).

The combination of thrombocytopenia with a prolonged PT and APTT are common laboratory findings in patients with liver failure (Tripodi et al., 2005; Caldwell et al., 2006). This might partially explain the current results as the liver plays a central role in haemostasis as it synthesizes the majority of coagulation factors as well as proteins involved in fibrinolysis (Monroe and Hoffman, 2006).

The fluctuation of APTT throughout the study period (significant shortening at four weeks relative to the zero and two weeks groups, then prolongation at six weeks) may be attributed to a transient stressful condition. It was reported that APTT is very sensitive to the 
level of factor VIII (an acute phase protein that is increased in response to inflammation or trauma). Hence, APTT may be misleadingly short during the acute phase reaction which when resolved, the APTT returns to normal. Short APTT may be also due to problems of samples gathering resulting in activation of coagulation within the collection tube (Chopin et al., 2006).

In the current research, significant increase in ADP-induced platelet aggregation is observed after tramadol administration at two weeks duration. Thereafter, it is significantly decreased at four weeks compared to the two weeks group. Interestingly, this parameter returns to be significantly increased after six weeks of tramadol administration compared to the four weeks group and even exceeding the percentages detected at the start of the study (zero level) inspite of being insignificant as shown in table (1).

In agreement with the present results, increased platelet aggregation was reported by Casella et al. (2013). The authors evaluated the in vitro effects of tramadol on adenosine diphosphate (ADP)-induced platelet aggregation in plasma of fed and fasted horses. Platelet aggregation was higher in fed than in fasted horses.

In contrast, Brondani et al. (2009) stated that perioperative subcutaneous administration of tramadol $(2 \mathrm{mg} / \mathrm{kg}$ one hour before induction of anesthesia and every eight hours up to 72 hours after surgery) did not interfere either with platelet aggregation or bleeding time.

In order to explain the effects of tramadol on the platelets in the present study, it is necessary to know that tramadol may act by various mechanisms which could in turn affect different hemostatic parameters. To begin with, tramadol inhibits serotonin and norepinephrine reuptake (Fouad et al., 2015).
It is well known that the inhibition of noradrenaline inhibits the release of prostacyclin (PGI2) and nitric oxide, both of which are known to be potent inhibitors of platelet aggregation (Jones et al., 1993).

Furthermore, tramadol-like morphine potentiates agonist-induced platelet aggregation by binding to $\alpha-2$ adrenoceptors in human platelets, with a resulting inhibition of adenylate cyclase, thereby reducing intracellular cyclic AMP formation followed by increased activation of phospholipase $\mathrm{C}$ and the $\mathrm{Na}+\mathrm{H}+$ exchanger. This leads to increased intracellular $\mathrm{Ca}^{2+}$ mobilization, and finally potentiation of platelet aggregation (Hsiao et al., 2003; Höcker et al., 2008). The foregoing facts could partially explain the increased percentage of ADPinduced platelet aggregation at two and six weeks of tramadol administration.

On the other hand, Galan et al. (2009) claimed that serotonin primes platelet activation and potentiates procoagulant response of platelets. A transporter protein is necessary to the transfer of serotonin into the platelet. Interestingly, tramadol is antagonist to this transporter, and because platelets do not produce serotonin, they are dependent on plasma uptake of serotonin. Thus, blockade of the serotonin transporter leads to serotonin depletion within the platelet, along with inhibition of platelet aggregation (de Abajo, 2011; Watts et al., 2012).

Moreover, tramadol acts as a local anesthetic and may induce changes in the membrane of platelets blocking the ion channels. Thus, it could inhibit alpha-granule release and thromboxane A2 signaling preventing platelet aggregation (Mert et al., 2007; Leppert, 2009). The previously mentioned opinions could explain the resultant decreased platelet aggregation at four weeks of tramadol administration after the initial increase at two weeks in the current work.

In conclusion, the current findings indicate that tramadol seems to affect hemostatic 
parameters in favour of bleeding tendency all over the six weeks of daily oral administration as evidenced by prolonged bleeding time, PT and APTT in addition to decreased ADPinduced platelet aggregation. Furthermore, bleeding time was still significantly prolonged inspite of the shortening of PT and APTT at four weeks and the significant increase in ADPinduced platelet aggregation, at two and six weeks. Further recovery abstinence period studies are recommended in order to assess the reversibility of these findings.

\section{References}

Adhikary, S. D. and Jacob, P. (2005): "Perioperative clinical tests of haemostasis and their implications". Indian Journal of Anaesthesia, 49:12-16.

Aldalou, A.; Abdel-Aziz, I. and Shahwan, O. (2014): "Impact of giving sildenafil (viagra)/ tramadol (tramal) combination on the blood of domestic rabbits". Journal of Science, 4(3):162-169.

Arnold, D.M., Kukaswadia, S., Nazi, I. et al. (2013): A systematic evaluation of laboratory testing for drug-induced immune thrombocytopenia. J. Thromb. Haemost.; 11: 169-176.

Bilir, A.; Akay, M. O.; Ceyhan, D. and Andic, N. (2014): "Does tramadol affect coagulation status of patients with malignancy?" Indian Journal of Pharmacology, 46(4): 413- 415.

Brondani, J. T.; Luna, S. P.; Marcello, G. C. and Padovani, C. R. (2009): "Perioperative administration of vedaprofen, tramadol or their combination does not interfere with platelet aggregation, bleeding time and biochemical variables in cats". Journal of Feline Medicine and Surgery, 11(6):503-509.

Caldwell, S. H.; Hoffman, M.; Lisman, T. et al. (2006): "Coagulation disorders and hemostasis in liver disease: pathophysiology and critical assessment of current management". Hepatology, 44 (4): 1039-1046.

Casella, S.; Giannetto, C.; Giudice, E. et al. (2013): "ADP-induced platelet aggregation after addition of tramadol in vitro in fed and fasted horses plasma". Research in Veterinary Science, 94(2): 325-330.

Chopin, N.; Floccard, B.; Sobas, F. et al. (2006): "Activated partial thromboplastin time waveform analysis: a new tool to detect infection". Critical Care Medicine, 34(6): 1654-1660.

Courtney, M. J. and Cabraal, D. (2001): "Tramadol vs diclofenac for posttonsillectomy analgesia". Archives of Otolaryngology-Head and Neck Surgery, 127(4): 385-388.

de Abajo, F. J. (2011): "Effects of selective serotonin reuptake inhibitors on platelet function". Drugs and Aging, 28(5): 345367.

Fouad, S.; Hassan, N.; Nassief, N.; ElHalawany, F. and Hussien, R. (2015): "Critical score as a predictor for progression of tramadol intoxication". Journal of Clinical Toxicology, 5(3): 1-9.

Galan, A. M.; Lopez-Vilchez, I.; Diaz-Ricart, M. et al. (2009): "Serotonergic mechanisms enhance platelet-mediated thrombogenicity". Journal of Thrombosis and Haemostasis, 102 (3) : 511-519.

Hafez, E. M., Issa, S. Y. and Abdel Rahman, S. M. (2015): Parenchymatous toxicity of tramadol: histopathological and biochemical study. J. Alcohol Drug 
Depend., 3:225. doi:10.4172/23296488. 1000225

Hallbäck, I.; Hägg, S.; Eriksson, A. C. and Whiss, P. A. (2012): "In vitro effects of serotonin and noradrenaline reuptake inhibitors on human platelet adhesion and coagulation". Pharmacological Reports, 64(4): 979-983.

Höcker, J.; Weber, B.; Tonner, P. H. et al. (2008): "Meperidine, remifentanil and tramadol but not sufentanil interact with $\alpha$ 2-adrenoceptors in $\alpha 2 \mathrm{~A}-, \alpha$-2B-and $\alpha-2 \mathrm{C}$-adrenoceptor knock out mice brain". European Journal of Pharmacology, 582(1):70-77.

Hsiao, G.; Shen, M. Y.; Fang, C. L. et al. (2003): "Morphine-potentiated platelet aggregation in in-vitro and platelet plug formation in in-vivo experiments". Journal of Biomedical Science, 10 (3): 292-301.

Işik, B. , Arslan, M. , Ozsoylar, O. and Akçabay, M. (2009): "Effects of preoperative lornoxicam versus tramadol on postoperative pain and adverse effects in adult tonsillectomy patients". Agri., 21(3):113-120.

Ismaiel, O. A. and Hosny, M. M. (2012): "Development and validation of a spectrophotometric method for the determination of tramadol in human urine using liquid-liquid extraction and ion pair formation". International Journal of Instrumentation Science, 1(3): 34-40.

Jones, C. J.; Defily, D. V.; Patterson, J. L. and Chilian, W. M. (1993): "Endothelium-dependent relaxation competes with alpha 1-and alpha 2adrenergic constriction in the canine epicardial coronary microcirculation". Circulation, 87(4): 1264-1274.
Leppert, W. (2009): "Tramadol as an analgesic for mild to moderate cancer pain". Pharmacological Reports, 61(6): 978-992.

Lisman, T.; Leebeek,F. W. and de Groot, P. G. (2002): "Haemostatic abnormalities in patients with liver disease". Journal of Hepatology, 37(2): 280-287.

Matthiesen, T.; Wöhrmann, T.; Coogan, T. and Uragg, H. (1998): "The experimental toxicology of tramadol: an overview". Toxicology Letters, 95(1): 63-71.

McMillan, C.J., Livingston, A., Clark, C.R. et al. (2008): "Pharmacokinetics of intravenous tramadol in dogs". Can. J. Vet. Res. 72: 325-331.

Mert, T.; Gunes, Y.and Gunay, I. (2007): "Local analgesic efficacy of tramadol following intraplantar injection". European Journal of Pharmacology, 558(1), 68-72.

Monroe, D. M. and Hoffman, M. (2006): "What does it take to make the perfect clot?" Arteriosclerosis, Thrombosis, and Vascular Biology, 26(1): 41-48.

Nna, V. U.; Oka, V. O.; Udefa, A. L.; Ofutet, E. O. and Ofem, O. E. (2016): "High doses of PDE5 inhibitors and tramadol reversibly alter haematological parameters in rats". Journal of Applied Pharmaceutical Science, 6 (4), 86-92.

Paniccia, R.; Priora, R.; Liotta, A. A. and Abbate, R. (2015):"Platelet function tests: a comparative review". Vasc. Health Risk Manag., 11: 133-148.

Quick, A. J.; Stanley-Brown, M. and Bancroft, F. W. (1935): "A study of the coagulation defect in hemophilia and in jaundice".The American Journal of the Medical Sciences, 190(4) : 501-510.

Saleem, R.; Iqbal, R.; Abbas, M. N. et al. (2014):"Effects of tramadol on histopathological and biochemical 
parameters in mice (Mus musculus) model". Global Journal of Pharmacology, 8(1):14-19.

Santacrocea, R. ; Bosiob, E.; Scionerib, V. and Mignone, M. (2018): "The new drugs and the sea: The phenomenon of narco-terrorism." International Journal of Drug Policy, 51: 67-68.

Slaughter, T.F. (2010): Coagulation. In: Miller's Anesthesia, Miller, R.D., editor., 7th Edition. California: Churchill Livingstone, P.P. 17671779.

Taromsari, M. R.; Badsar, A. R.; Bahrami, F.; Jahanseir, K. and Fallah-Karkan, M. (2012): "Clinical and laboratory findings in patients with tramadol intoxication referred to Razi hospital during 2005-2006". Iranian Journal of Toxicology, 6(16): 605-609.

Tripodi, A.; Salerno, F.; Chantarangkul, V. et al. (2005): "Evidence of normal thrombin generation in cirrhosis despite abnormal conventional coagulation tests". Hepatology, 41(3): 553-558.

Watts, S. W.; Morrison, S. F.; Davis, R. P. and Barman, S. M. (2012):"Serotonin and blood pressure regulation". Pharmacological Reviews, 64(2): 359-388.

World Health Organization "WHO" (2014): Tramadol. Retrieved from http://www.who.int/medicines/areas/ quality_safety/6_1_Update.pdf. 


\section{تكرار تعاطى التزامادول يحفز النزف فى الجرذان البيضاي}

\section{هانم محمد رشدى'، رانيا حامد عبد الرحمن'، حنان عزام'، آمال عبد السلام البقرى'}

من قسمى الطب الثرعي والسموم الإكلينيكية' والباثولوجيا الإكلينيكيةّ ـ كلية الطب، جامعة المنصورة

يعد تعاطي التر امادول مشكلة صحية كبرى كما أن تأثيره على تخثر الدم أظهر نتائج مثيرة للجدل. لذا كان الهدف من هذا البحث هو در اسة التأثير ات السمية شبه المزمنة للتر امادول على بعض معاملات منع عملية تخثر

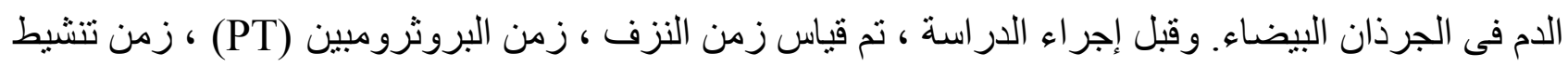

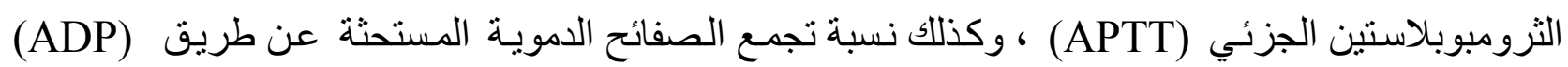

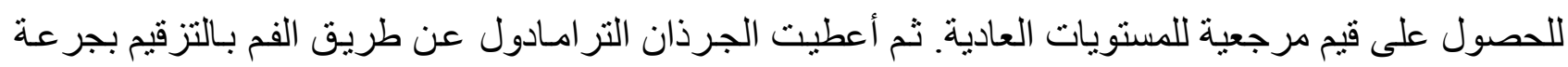

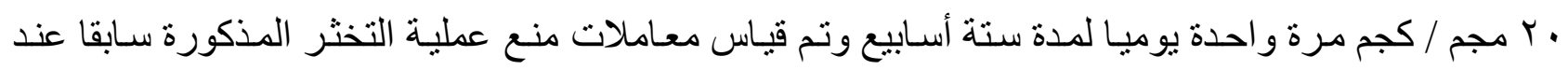

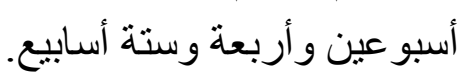

وقد أثبتت النتائج أن التر امادول قد عزز النزف على مدى الأسابيع الستة للدر اسة كما بتضح من طول زمن النزف ، و التأثير الملحوظ والمتفاوت على زمن البروثرومبين و زمن تنشيط الثرومبوبلاستين الجزئي ، وكذلك تناقص تجمع الصفائح الدمويـة المستحثة بواسطة ADP و على الرغم من الزيـادة الكبيرة في تجمـع الصفائح

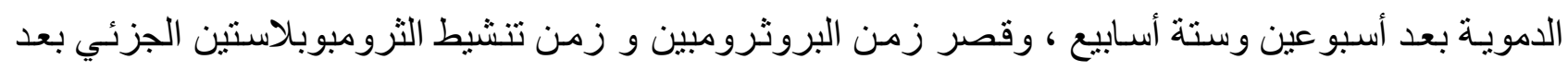

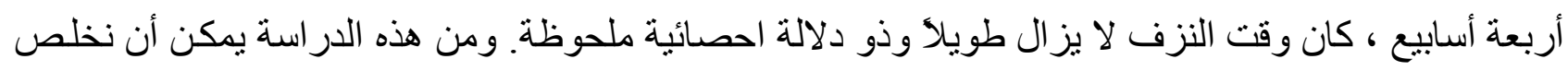

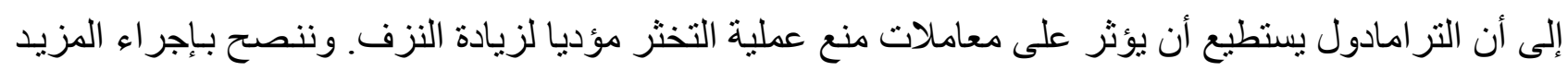

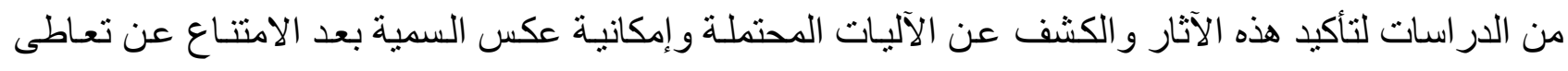
التر امادول. 